\title{
Assessment of Continuous Oil and Gas Resources of Solimões, Amazonas, and Parnaíba Basin Provinces, Brazil, 2016
}

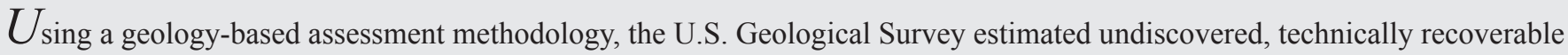
mean continuous resources of 5 billion barrels of oil and 47 trillion cubic feet of gas in the Paleozoic Solimões, Amazonas, and Parnaíba Basin Provinces, Brazil.

\section{Introduction}

The U.S. Geological Survey (USGS) assessed undiscovered, technically recoverable continuous oil and gas resources within the Paleozoic Solimões, Amazonas, and Parnaíba Basin Provinces of Brazil (fig. 1). These Paleozoic basins share similar geologic characteristics that relate to oil and gas resource potential: (1) a progression from rifting, thermal sag, wrench faulting, and compression; (2) Devonian organic-rich shales deposited in the sag phase are the principal petroleum source rocks; (3) thermal maturation is a result of both burial and heating by widespread intrusives; and (4) geologic risk is based on the retention of oil and gas in the Devonian source rocks. The geologic definition of total petroleum systems (TPSs) and assessment units (AUs) reflect these common characteristics. For the Solimões Basin Province, the USGS defined a Devonian Jandiatuba TPS and the Solimões Jandiatuba Continuous Gas AU within this TPS. The Devonian Barreirinha TPS and the Amazonas Barreirinha Continuous Oil and the Amazonas Barreirinha Continuous Gas AUs were defined within the Amazonas Basin Province. The Devonian Pimenteiras TPS and the Parnaíba Pimenteiras Continuous Oil and the Parnaíba Pimenteiras Continuous Gas AUs were defined within the Parnaíba Basin Province. Published data on source-rock quality, thermal maturation, and thickness for the Solimões Basin (Mosmann and others, 1986; Mello and others, 1994), Amazonas Basin (Mosmann and others, 1986; Gonzaga and others, 2000), and the Parnaíba Basin (De Oliveira and Mohriak, 2003; Petersohn, 2011; De Miranda, 2014) were critical for TPS and AU definitions. These three TPSs share Devonian source rocks that are dominated by Type II marine kerogen; contain greater than 2 weight percent total organic carbon, as much as 8 weight percent; and have thicknesses of organic-rich shale greater than 15 meters.

\section{Geologic Model for Assessment}

With common geologic characteristics, the geologic model for the assessments summarized herein applies to each TPS. The geologic model is for oil and gas to have been generated by burial of source rocks beginning in the Permian and by the emplacement of dolerite dikes and sills in the Late Triassic to Early Cretaceous. In this model, oil and gas are partially retained within the matrix of organic-rich Devonian shales. Input for shale-oil assessment was modeled using vertical wells.

Assessment input data for the five assessment units are shown in table 1. Well drainage areas, estimated ultimate recoveries, and success ratios are taken from U.S. shale-oil and shale-gas analogs.

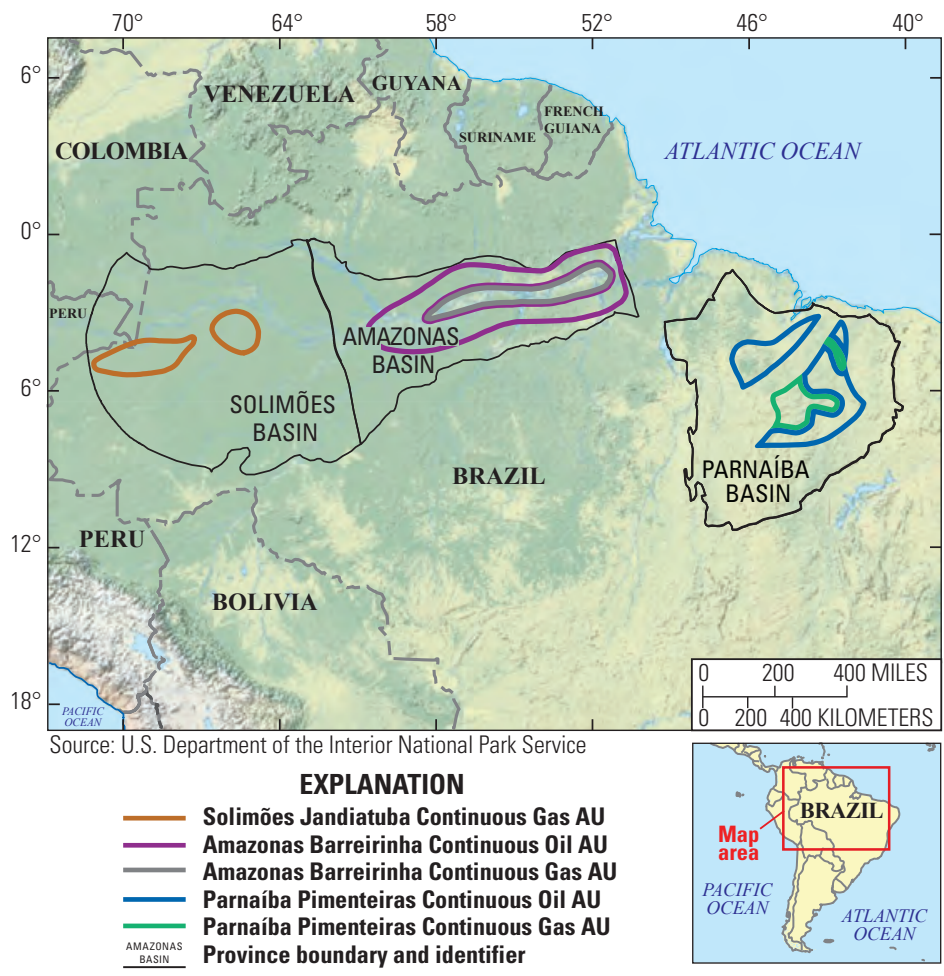

Figure 1. Location of the Solimões, Amazonas, and Parnaíba Basin Provinces, Brazil, and the five assessment units (AUs) defined in this study.

\section{Undiscovered Resources Summary}

The USGS quantitatively assessed undiscovered continuous oil and gas resources within the Solimões, Amazonas, and Parnaíba Basin Provinces of Brazil (table 2). For continuous oil resources, the estimated mean total is 5,019 million barrels of oil (MMBO), or 5 billion barrels of oil, with an F95-F5 range from 0 to 15,584 MMBO. For continuous gas resources, the estimated mean total is 47,201 billion cubic feet of gas (BCFG), or 47 trillion cubic feet of gas, with an F95-F5 range from 0 to 151,542 BCFG. For natural gas liquids, the estimated mean total is 897 million barrels of natural gas liquids (MMBNGL) with an F95-F5 range from 0 to 3,006 MMBNGL. For oil and gas accumulations, zeros at the F95 fractile reflect the interpretation of geologic risk (AU probability less than 1.0) on the potential occurrence of one well of minimum EUR in the AU.

Of the total resources, 68 percent $(3,437 \mathrm{MMBO})$ of the continuous oil and 72 percent $(33,816 \mathrm{BCFG})$ of the continuous gas is in the Amazonas Basin Province. The major source of geologic risk for continuous resources is the retention of oil or gas in the source rock following structural deformation and emplacement of intrusives. 
Table 1. Key assessment input data for five continuous assessment units in the Solimões, Amazonas, and Parnaíba Basin Provinces, Brazil. [AU, assessment unit; \%, percent; EUR, estimated ultimate recovery per well; BCFG, billion cubic feet of gas; MMBO, million barrels of oil; MMBNGL, million barrels of natural gas liquids. Well drainage areas, EURs, and success ratios are taken from U.S. shale-oil and shale-gas analogs. The average EUR input is the minimum, median, maximum, and calculated mean. Shading indicates not applicable]

\begin{tabular}{|c|c|c|c|c|c|c|c|c|}
\hline \multirow[b]{2}{*}{ Assessment input data } & \multicolumn{4}{|c|}{ Solimões Jandiatuba Continuous Gas AU } & \multicolumn{4}{|c|}{ Amazonas Barreirinha Continuous Gas AU } \\
\hline & Minimum & Mode & Maximum & $\begin{array}{l}\text { Calculated } \\
\text { mean }\end{array}$ & Minimum & Mode & Maximum & $\begin{array}{l}\text { Calculated } \\
\text { mean }\end{array}$ \\
\hline Potential production area of AU (acres) & 1,200 & $4,000,000$ & $16,804,000$ & $6,935,067$ & 1,200 & $4,508,000$ & $18,033,000$ & $7,514,067$ \\
\hline Average drainage area of wells (acres) & 80 & 120 & 160 & 120 & 80 & 120 & 160 & 120 \\
\hline Percentage of area untested in $\mathrm{AU}$ & 100 & 100 & 100 & 100 & 100 & 100 & 100 & 100 \\
\hline Success ratios $(\%)$ & 10 & 50 & 90 & 50 & 10 & 50 & 90 & 50 \\
\hline Average EUR (BCFG) & 0.08 & 0.2 & 1.2 & 0.256 & 0.08 & 0.2 & 1.2 & 0.256 \\
\hline AU probability & 0.6 & & & & 0.8 & & & \\
\hline \multirow[b]{2}{*}{ Assessment input data } & \multicolumn{4}{|c|}{ Amazonas Barreirinha Continuous Oil AU } & \multicolumn{4}{|c|}{ Parnaíba Pimenteiras Continuous Oil AU } \\
\hline & Minimum & Mode & Maximum & $\begin{array}{c}\text { Calculated } \\
\text { mean }\end{array}$ & Minimum & Mode & Maximum & $\begin{array}{c}\text { Calculated } \\
\text { mean }\end{array}$ \\
\hline Potential production area of AU (acres) & 800 & $12,159,000$ & $48,637,000$ & $20,256,600$ & 800 & $7,530,000$ & $30,121,000$ & $12,550,600$ \\
\hline Average drainage area of wells (acres) & 40 & 80 & 120 & 80 & 40 & 80 & 120 & 80 \\
\hline Percentage of area untested in $\mathrm{AU}$ & 100 & 100 & 100 & 100 & 100 & 100 & 100 & 100 \\
\hline Success ratios (\%) & 10 & 50 & 90 & 50 & 10 & 50 & 90 & 50 \\
\hline Average EUR (MMBO) & 0.01 & 0.03 & 0.1 & 0.034 & 0.01 & 0.03 & 0.1 & 0.034 \\
\hline AU probability & 0.8 & & & & 0.6 & & & \\
\hline \multirow[b]{2}{*}{ Assessment input data } & \multicolumn{4}{|c|}{ Parnaíba Pimenteiras Continuous Gas AU } & & & & \\
\hline & Minimum & Mode & Maximum & $\begin{array}{l}\text { Calculated } \\
\text { mean }\end{array}$ & & & & \\
\hline Potential production area of AU (acres) & 1,200 & $2,500,000$ & $10,640,000$ & $4,380,400$ & & & & \\
\hline Average drainage area of wells (acres) & 80 & 120 & 160 & 120 & & & & \\
\hline Percentage of area untested in $\mathrm{AU}$ & 100 & 100 & 100 & 100 & & & & \\
\hline Success ratios (\%) & 10 & 50 & 90 & 50 & & & & \\
\hline Average EUR (BCFG) & 0.08 & 0.2 & 1.2 & 0.256 & & & & \\
\hline AU probability & 0.6 & & & & & & & \\
\hline
\end{tabular}

Table 2. Assessment results for five continuous assessment units in the Solimões, Amazonas, and Parnaíba Basin Provinces, Brazil.

[MMBO, million barrels of oil; BCFG, billions of cubic feet of gas; MMBNGL, million barrels of natural gas liquids. Results shown are fully risked estimates. For gas accumulations, all liquids are included under the NGL (natural gas liquids) category. F95 represents a 95-percent chance of at least the amount tabulated; other fractiles are defined similarly. Fractiles are additive under the assumption of perfect positive correlation. Shading indicates not applicable]

\begin{tabular}{|c|c|c|c|c|c|c|c|c|c|c|c|c|c|c|}
\hline \multirow{3}{*}{$\begin{array}{l}\text { Total petroleum systems } \\
\text { and assessment units (AUs) }\end{array}$} & \multirow{3}{*}{$\begin{array}{c}\text { AU } \\
\text { prob- } \\
\text { ability }\end{array}$} & \multirow{3}{*}{$\begin{array}{c}\text { Accu- } \\
\text { mulation } \\
\text { type }\end{array}$} & \multicolumn{12}{|c|}{ Total undiscovered resources } \\
\hline & & & \multicolumn{4}{|c|}{ Oil (MMBO) } & \multicolumn{4}{|c|}{ Gas (BCFG) } & \multicolumn{4}{|c|}{ NGL (MMBNGL) } \\
\hline & & & F95 & F50 & $\mathrm{F5}$ & Mean & F95 & F50 & F5 & Mean & F95 & F50 & F5 & Mean \\
\hline \multicolumn{15}{|c|}{ Devonian Jandiatuba Total Petroleum System } \\
\hline Solimões Jandiatuba Continuous Gas AU & 0.6 & Gas & & & & & 0 & 2,188 & 16,186 & 4,320 & 0 & 63 & 491 & 129 \\
\hline \multicolumn{15}{|c|}{ Devonian Barreirinha Total Petroleum System } \\
\hline Amazonas Barreirinha Continuous Oil AU & 0.8 & Oil & 0 & 2,649 & 10,009 & 3,437 & 0 & 17,734 & 82,378 & 27,522 & 0 & 279 & 1,185 & 385 \\
\hline Amazonas Barreirinha Continuous Gas AU & 0.8 & Gas & & & & & 0 & 4,329 & 20,040 & 6,294 & 0 & 126 & 609 & 189 \\
\hline \multicolumn{15}{|c|}{ Devonian Pimenteiras Total Petroleum System } \\
\hline Parnaíba Pimenteiras Continuous Oil AU & 0.6 & Oil & 0 & 934 & 5,575 & 1,582 & 0 & 3,536 & 22,568 & 6,323 & 0 & 74 & 513 & 139 \\
\hline Parnaíba Pimenteiras Continuous Gas AU & 0.6 & Gas & & & & & 0 & 1,404 & 10,370 & 2,742 & 0 & 27 & 208 & 55 \\
\hline Total undiscovered continuous resources & & & $\mathbf{0}$ & 3,583 & 15,584 & 5,019 & $\mathbf{0}$ & 29,191 & 151,542 & 47,201 & $\mathbf{0}$ & 569 & 3,006 & 897 \\
\hline
\end{tabular}

\section{References Cited}

De Miranda, F.S., 2014, Pimenteiras Shale - Characterization of an atypical unconventional petroleum system, Parnaíba Basin, Brazil: American Association of Petroleum Geologists Search and Discovery Article No. 10639, accessed September 23, 2016, at http://www.searchanddiscovery.com/pdfz/documents/2014/10639demiranda/ ndx_demiranda.pdf.html?q=\%252BtitleStrip\%253Aparnaiba+-isMeetingAbstract $\% 253$ Amtgabsyes.

De Oliveira, D.C., and Mohriak, W.U., 2003, Jaibaras trough—An important element in the early evolution of the Parnaíba interior sag basin, northern Brazil: Marine and Petroleum Geology, v. 20, p. 351-383.

Gonzaga, F.G., Gonçalves, F.T.T., and Coutinho, L.F.C., 2000, Petroleum geology of the Amazonas Basin, Brazil—Modeling of hydrocarbon generation and migration, in Mello, M.R., and Katz, B.J., eds., Petroleum systems of South Atlantic margins: American Association of Petroleum Geologists Memoir No. 73, p. 159-178.

Mello, M.R., Koutsoukos, E.A.M., Mohriak, W.U., and Bacoccoli, Giuseppe, 1994, Selected petroleum systems in Brazil, in Magoon, L.B., and Dow, W.G., eds., The petroleum system - From source to trap: American Association of Petroleum Geologists Memoir No. 60, p. 499-512.

Mosmann, Raul, Falkenhein, F.U.H., Gonzalves, Alfredo, and Filho, F.N., 1986, Oil and gas potential of the Amazon Paleozoic basins, in Halbouty, M.T., ed., Future petroleum provinces of the world: American Association of Petroleum Geologists Memoir No. 40, p. 207-241.

Petersohn, Eliane, 2011, Brazil Round 9-Parnaíba Basin: Brazil National Agency of Petroleum, Natural Gas and Biofuels (ANP), 39 p., accessed December 28, 2016, at http://www.brasil-rounds.gov.br/round9/arquivos_r9/palestras/Parnaiba(ingles).pdf.

\section{For More Information}

Assessment results also are available at the USGS Energy Resources Program website at http://energy.usgs.gov.

\section{Brazil Basin Provinces Assessment Team}

Christopher J. Schenk, Marilyn E. Tennyson, Timothy R. Klett, Thomas M. Finn, Tracey J. Mercier, Sarah J. Hawkins, Stephanie B. Gaswirth, Kristen R. Marra, Michael E. Brownfield, Phuong A. Le, and Heidi M. Leathers-Miller 